\title{
Languages of Science in the Era of Nation-state Formation: The Israeli Universities and Their (non)Participation in the Revival of Hebrew ${ }^{1}$
}

\author{
Nina G. Kheimets \\ Department of English, Bar-llan University, Jerusalem, Israel
}

Alek D. Epstein

Department of Sociology and Political Science, Open University of Israel

This paper presents sociological analysis of the linguistic and cultural identity of two of Israel's most influential and high-ranked universities during their formative years, that were also the de facto formative years of the Israeli state-in-the-making (1924-1948). We argue that the influence of external universal factors on a nationstate was sometimes crucial long before the period characterised by social scientists as an era of globalisation. Influenced by European nationalism, the leaders of the Zionist movement emphasised the importance of the restoration of Hebrew as a national language. In various European national movements the universities played a central role in the revival or creation of a national culture: the language, the national epic, the folklore were all cultivated and nurtured by the universities. This was not the case in the Jewish renaissance: the cultural revolution took place outside academia. The most cardinal phenomenon in this context - the revival of the Hebrew language - had almost no connection whatsoever with academic bodies. The phenomenon discussed in this essay should not be underestimated by historians and sociologists, especially provided the fact that Israel is traditionally perceived as one of the most successful and impressive instances of nation building in the 20th century.

Keywords: revival of Hebrew, nation building, globalisation, national university, higher education in Israel

\section{Science and Language Repertoire: Some Theoretical Considerations}

The interrelations between the scholars and language ideology have always been complicated. In various countries during various periods scientists found themselves among the most radical adherents of linguistic nationalism, as well as in the milieu of faithful enthusiasts of globalisation, who were pushing forward the Esperanto project or advocating for the total language shift to English.

Historically, the paradigms of knowledge which supported the rise of modern science appeared to expand the social matrix of the community of knowers beyond the former limits of a privileged, exclusive elite of scholars. Men of knowledge, such as Galileo and Descartes, decided to write their works in the vernacular rather than in Latin, avowedly for the purpose of 
appealing against the learned world to an intelligent reading public (see Butterfield, 1966: 180-181). Eighteenth century thinkers, such as Diderot, hoped that language of science would be transparent and open to validation by a wide community of rational people, and as such would contribute to the struggle against religious dogmas and pseudo-scientific postulates. In other words, in those days, scientists were unequivocally interested in tearing a touch of exclusiveness from the scientific and semi-scientific discourse and used the language clear to laymen in order to mobilise their support.

As described by Karl Mannheim (1956 [1933]: 133-135) in his classical study entitled The Problem of the Intelligentsia, a unique type of intellectual community arose after the Renaissance in a growing number of societies. In the end of the 15th century the Florentine Academia della Crusca set the original pattern to be followed by a number of 'language societies' in Italy, Switzerland, Holland and Germany. These societies comprised varied ranks of the aristocracy as well as scholars and educated commoners, and a princely patron. Even though commoners played a subordinate role in these language societies, it would be a mistake not to see in them the growth of a broad and inclusive social orientation which transcended the feudal horizon towards an early form of national consensus. Prince Louis, the patron of the best known of these language societies, the 'fruchtbringende Gesellschaft' of Kothen, declined the suggestion to convert the fraternity into an exclusive order of knights, on the ground that the society 'is solely concerned with the German language and the good virtues rather than with knightly conduct...'. These societies cultivated the vernacular of the middle classes and taught indifference to one's social origin in matters of common concern. Most important, they established channels of interclass communication and assembled local elites who learned how to use them.

Jacques Le Goff (1993 [1957]), in his Intellectuals in the Middle Ages, argued that the 12th century monks in abbeys in Spain, Italy and other countries who translated various texts from Arabic and Ancient Greek into Latin were the first scientists and intellectuals of the Christian word. The 12th century brought with it a new feeling in some circles that intellect is the key to effective political power; the scholars of an expanding Europe hungrily grabbed at any knowledge they could find. The scientific and mathematical knowledge of the Greeks and Arabs began to pour across the borders of Christendom: after 1100, Euclid's Elements gained increased prominence; in 1126 Adelard of Bath brought Al-Khwarizmi's trigonometry to the west; in 1145 Robert of Chester translated Al-Khwarizmi's Algebra; Ptolemy's Almagest was translated from the Greek in 1160. Throughout centuries hundreds of intellectuals in various countries had been described by their biographers as enlighteners whose selfappointed task was to spread the literary culture of the educated minority to a wider audience, and by doing so to strengthen social unity. Transmission of ideas by means of translation and adaptation of texts originally written in foreign languages until recently were considered the intellectuals' 'natural' responsibility. The intellectuals served as intercultural bridge-makers, their knowledge of various languages being among the most landmark attributes, which provided them with recognition and respect. However, this role of 
intellectuals as intercultural bridge-makers has been challenged drastically by three, although contradictory, tendencies.

First of all, the standardisation and universalisation of scientific languages turned out to be neither a process of developing a uniform language, which would be common to scientists and laymen, nor even a process of unifying the scientific universe of discourse. It was rather a process of progressive differentiation and refinement of specialised languages which were 'legalised' by a series of agreements on the part of small groups of professionals. From the point of view of the lay public, the transition from the prescientific knowledge to the scientific one was in fact but the substitution of one form of esoteric knowledge for another. In both cases, the laymen could not rely on their own judgment but remained dependent on indirect evidence and on the authority of others (Ezrahi, 1974: 218-219). Since the end of the 18th century there has been the decline of the concept of knowledge as the representation of the visible. Alvin Gouldner in his famous book entitled The Future of Intellectuals and the Rise of the New Class claimed that there is a special solidarity among scientists and academics brought by the sharing of a language; he defined the language of science as a sociolect. In Gouldner's (1979: 30) own words:

As a language, [this sociolect] unifies in much the same way as ordinary languages, say French or German. Just as French or German are boundary-establishing, unifying elements, making it easier for members of the nation to communicate with one another, but making it harder for them to do so with people who do not speak their language, so, too, does [this sociolect] unify those who use it and establish distance between themselves and those who do not.

Gouldner's indictment against the self-isolated scientists has received sustained commentary. Russell Jacoby (1987) argued that after World War II 'professors neither looked backwards or sideways; they kept their eyes on professional journals, monographs and conferences'. What has thereby been destroyed is 'a commitment not simply to a professional or private domain but to a public word - and a public language, the vernacular'.

The rise of European secular nationalism became the second trend that corrupted the role of intellectuals as intercultural bridge-makers. Imaginative intellectuals were among the most active and productive inventors of nations. In various societies the idea of a nation emerged in the 18th and 19th centuries in the minds of small groups of intellectuals and later has been diffused - or imposed - on the population. The linking of language with identity and with nation is in large part a product of German romanticism. The consideration of vernaculars as determinants of nations goes back to the philosophy of Johann Gottfried Herder, who published in 1772 his first major philosophical work, Ueber den Ursprung der Sprache [On the Origin of Language]. Herder believed that language was man's link with the past, that reveals to him the thoughts, feelings and prejudices of past generations, which thus become deeply ingrained in his own consciousness. He, in turn, again by means of language, perpetuates and enriches these for the benefit of posterity. In this way language embodies the living manifestation of historical growth and the 
psychological matrix in which man's awareness of his distinctive social heritage is aroused and deepened. Herder identified those sharing a particular historical tradition grounded in language with the Volk, or nationality, and it was in this essentially spiritual quality that he saw the most natural and organic basis for political association (see Edwards, 1985: 23-46). In France and Russia, as well as in Germany, Italy, various east European and Balkan countries (Serbia, Romania, Bulgaria and others), which gained an independent political status as unified nation-states between 1860 and 1918, intellectuals played a crucial role in creating anti-modernist nationalist ideologies, which rejected the rational universalism of the Enlightenment and its almost absolute faith in science. Later many European intellectuals found themselves among the protagonists and admirers of Fascism and Nazism. Even when it finally did emerge, the intellectuals' opposition was directed far more against the brutality and vulgarity of the newly established regimes than against their ideologies. Everywhere in Europe, the political revolt was preceded by the intellectual one. Scholars, writers and artists abandoned their mission of dialogue-moderators between various social and national groups; their fear that the high culture might be swamped by the mass society lead to the rejection of a dialogue with a wider audience. Intellectuals discovered the hidden history of their nations' ethnic communities and stressed the role of a particularistic language as a central component of the national legacy.

In contemporary nation-states, a legitimate language is generally inseparably bound to the definition of the national culture and collective history. As early as 1794 in France, Gregoire, a leader of the Convention, presented a report entitled 'The Need to Eradicate the Patoits and to Universalize the Use of the French Language'. The report's conclusion was that the linguistic unity of France and the triumph of French in France were an integral part of the Revolution. The dominant ideology in France ever since has been that access to the French language gives Frenchmen access to instruction, and through instruction to enlightenment. The existence of a multitude of languages is a hindrance to the free communication of minds, and loyalty to France means loyalty to the French language; it was in accordance with this attitude that in 1793, in Alsace, a 'linguistic terror' involved the establishment of French schools in order to destroy separatist aspirations (see Grillo, 1989).

After World War II in the postcolonial countries the tendencies in general were quite similar. As Edward Shils claimed (1990: 301), 'Intellectuals of colonial or quasi-colonial countries have a strong sense of nationality - their sense of their own "nationality" is ordinary far stronger than it is in the rest of the society'. The linguistic dimension played an important part in the construction of their nationalist worldview. For example, Mahatma Gandhi, 'the founding father' of the modern India - the largest country among all those that proclaimed their political independence after 1945 - was a determined advocate of Hindustani as the national medium to be taught as a required second language in all schools together with the respective regional languages, but rejected to guarantee any status to English besides its recognition as the language of diplomacy and foreign trade (Bendix, 1969: 288). The fact that Gandhi himself spent several years studying law in London seems to reinforce Edward Shils' thesis that the nationalism was fed 
by the extensive use of a foreign language in daily intellectual life. Shils (1972 [1960]: 401-402) argued that

The intellectuals' very large amount of reading in French and English and their feeling of continued dependence on these cultures, their continuing and still necessary employment of French or English for their own cultural creations and even for political, administrative, and judicial purposes, and their awareness of the slow and painful course through which their nation must pass before its own language become adequate to the requirements of modern life, cannot avoid touching their sensibilities. The constant reaffirmation of their nationalistic attachment is an effort to assuage this wound.

Today the trends both similar to those described above and different from them are evident in some newly independent countries. For example, the Georgian intellectual elite consists of the 'old' (or, more pejoratively, 'nomenclature') intelligentsia, on the other hand, and the 'new' (Westerntype) intellectuals, on the other. Georgian philosopher and political scientist Gia Nodia notes that the 'old' ones and the 'new' ones use different types of discourse. As a matter of fact, they hardly understand each other: the 'old' ones speak Russian as their second language (German coming next), while the 'new' ones mostly speak English. They do not perceive the Georgian language as sufficient for intellectual communication in the contemporary world and recognise English (as opposed to Russian) as an integral part of the linguistic repertoire of their national and political independence, although at least a half of their personal libraries is made up of Russian books. Russian, associated with the imperial aspirations of the former USSR, has turned from a privileged language of culture into merely a language - at best (see Shatirishvili, 2003).

As far as the scientific world is concerned, the reference to the international scene has always been an endemic aspect of its development, even when one could by no means call the world where this orientation expressed itself, a 'globalised world'. Nevertheless, Americanisation (which is often called 'globalisation'), particularly in the world of science and technology, has become the third sociopolitical trend that drastically changed the role of academics vis-à-vis the societies they live in. Modern science being a child of the first industrial revolution, the heavy dependence on science and technology during World War II resulted in an immense growth in scientific activity. The USA, by virtue of the fact that its scientific infrastructure was not only undamaged by the war, but also benefited from the influx of immigrant scholars, assumed leadership in science and technology.

It is an established fact that progress in science depends on the accumulation of a written record of all previous research; that is, science requires great information storage and retrieval system. The invention of the computer made those information storage and retrieval systems geometrically larger and more accessible. Those who conduct the greatest amount of research require the greatest amount of information from those information networks, and they naturally also contribute the greatest amount of new information to them. As much of the science and technology research in the 1950s and 1960s was 
conducted in English, most contributions to the great information storage networks were written in English. As mentioned by Kaplan (2001: 12):

Not only is English the undisputed language of science, but because of the importance of the computer in the internationalisation of English, the English-speaking nations may hold a virtual cartel on scientific information because the international information systems are organized according to an English-based sociology of knowledge. Even research and development functions in non-English states are impacted, since it is necessary to be able to search scientific literature in English and according to its sociology of knowledge.

Although the influence of globalisation is opposite to that of nationalism, both cases are predominantly built on the academic community's monolingual ideology: the same (let it be English) language in the case of globalisation and each nation's particular vernacular in the case of nationalism. The demand for academics' and scientists' multilingualism is abandoned in both cases.

The case, discussed in this paper, is of particular interest due to the wide variety of ideological, cultural and linguistic opportunities available to the Jewish intellectuals in the Mandatory Palestine. This variety created unique circumstances which could provide each one of the aforementioned three tendencies with relatively equal chances to take over.

On the one hand, this period ended at the high point of Jewish nationalism - in 1948 an independent State of Israel was established. Jewish nationalism in the latter part of the 19th century took two distinct paths: a nonterritorial cultural nationalism that chose standardised and secularised Yiddish as its language, and a territorialist socialist movement that aimed to develop a new Hebrew man, speaking Hebrew in the newly redeemed land. The battle between the two ideologies and languages was fought both in Europe and in Palestine, with Hebrew becoming the victor in the latter. Ideological Jewish nationalists committed to the revival of language and identity in their former homeland. It has become a common point that a sweeping social mobilisation of Eretz-Israel intellectuals took place during the pre-state period in order to achieve this political goal. Therefore, the first hypothesis is that in such circumstances the nationalistic orientation of most intellectuals and scientists would predetermine the choice of Hebrew as an ultimate language of communication, publication and teaching, and that native speakers of Hebrew would become the most privileged and promoted group of intellectuals.

On the other hand, its geographical position as a land bridge connecting Europe, Asia and Africa, its resulting long history of conquest and reconquest, and its status as the point of focus of four major world religions (the birthplace of Judaism and Christianity, significant also to Islam), all assure Palestine/ Eretz-Israel of a long tradition of complex and ever-changing multilingualism. The outcome of dispersion, on the eve of the development of Zionism, is best illustrated by the nature of Diaspora Jews' linguistic variety and the dozens of Jewish languages existing throughout the world: Parsic in Persia; Bukharic in central Asia; Tatic, Armenic and Gurjic in the Caucasus and Georgia; Yevanic in Egypt and Greece; Italkian in Italy; Spanyolish, or Ladino, in the Mediterranean countries; Arvic and Temanic in Asia; Aravic in eastern north 
Africa; Yiddish in Eastern Europe and Germany; Crimshak in the Crimea; Indo-Aryan and Dravidian Jewish languages in India; Karaite in Eastern Europe, etc. By the close of the 19th century, Palestine was already undergoing a change in its multilingual pattern (for detailed discussion see Spolsky \& Cooper, 1991). The language of government, in the main restricted in its use to soldiers and officials, was Turkish. Peasants and town-dwellers spoke local dialects of Arabic. Classical Arabic was the written language of the educated elite. Sephardic Jews spoke Arabic too, but inside the community their language was Ladino (a Jewish language based on Spanish). European languages were being introduced and encouraged by missionary Churches and powerful foreign consuls. French had an important status, and German was supported by an explicit government language diffusion policy (see Spolsky \& Cooper, 1991). Most Ashkenazic Jews who started to arrive from Eastern Europe in the second half of the 19th century spoke Yiddish, but they also brought some coterritorial vernaculars like Russian, Polish and Hungarian with them. Therefore, the second hypothesis (alternative to the previous one) is that the Eretz-Israel intellectual community would be characterised by extreme multilingualism, whereas the intellectuals' mission as bridge-makers and translators would be of great importance. There also could be a counter hypothesis: one can hardly expect that a national university will be set up on the basis of particularistic languages, especially in a setting where cultural and linguistic unification is at the heart of an ongoing nationbuilding project. In any case, both assumptions should be tested empirically.

Third, the consequences of the status of English as the main language of government under British Mandatory rule should not be underestimated. During and after World War II the birth of the United Nations, the invention of the computer, the expansion of American influence and power and the geometric growth of scientific and technological innovations, all occurring coincidentally at the same time, created the conditions which made English the predominant language of science and technology. Israeli academics could not keep aloof from these worldwide trends. Therefore, the third hypothesis is that, as elsewhere in the world, English would become the dominant language within the Israeli scientific and semi-scientific community. The dilemma of local-oriented nationalism versus the international calling of research and science created the focus of the current study.

The patterns of academics' communication within the general community should also be investigated. Is Jacoby's critics of 'professors [who] neither look backwards or sideways [and] keep their eyes on professional journals, monographs and conferences' valid in the case of Eretz-Israel scholars? Did they develop their own sociolect, distinctive from the general community's vernacular? These questions, as well as the abovementioned hypotheses, constitute the main research questions of the current study.

\section{Revitalisation of Hebrew versus the Hebrew University}

The story of the revitalisation of Hebrew has been told repeatedly. Zionists proclaimed a number of specific aims; to develop Hebrew as a spoken language and the foundation of a national consensus was one of the most 
important of them (Halpern \& Reinharz, 2000: 8). Proponents of cultural Zionism insisted on Hebrew as the language of instruction not only in Jewish studies, but in all subjects, including the most technical - a proposal that implied an extraordinary, deliberately accelerated development of a language that has been confined to very narrow uses for centuries. As a spoken language and the recognised national tongue, Hebrew has become one of the most important symbols of the Jewish sovereignty and statehood. The dream has become true: by the 1920s, Hebrew was the major language in the public arena of the Jewish community of Palestine (Bachi, 1956) and a native language to hundreds of native-born Sabras, although many leading academic and literary figures were still far from speaking it comfortably.

The British Mandatory government (due to the lobbying of the Zionists) bolstered the standing of Hebrew in several ways. First, shortly after General Allenby occupied the country in 1918, the use of German in schools was banned and the teachers interned. Even before the Mandate was formally proclaimed, the British Government had been persuaded that Hebrew was the language of the Jewish population, and British regulations and the Mandate itself established Hebrew as an official language alongside Arabic and English. Second, to minimise its financial commitment to the mandated territory, the British left the Jewish community to conduct its own educational system, restricting their involvement to providing some subsidies for the building of schools in Arab villages. Thus, as the language of instruction in Jewish schools and in the university, Hebrew grew into a language well equipped to deal with modern life and technology. In this, it was helped by the establishment of a Language Committee, to be renamed The Hebrew Language Academy after independence.

Under British Mandatory rule, while English was the main language of government, the Jewish and Arabic communities remained distinct, with separate school systems. Contact bilingualism developed, with English serving both communities as a potential language of wider communication. And yet, new Jewish immigrants who wished to integrate needed to acquire Hebrew, the language of work, education and public cultural life. By 1948, when the state of Israel was established, Hebrew was the principal language of the bulk of the Jewish population (Bachi, 1956). In the next decade, large numbers of new immigrants arrived, but their high linguistic heterogeneity contributed to the rapid acceptance of Hebrew by the new arrivals and their children. Cooper (1984) indicated other factors contributing to the speed of accepting Hebrew. These included age on arrival (the younger, the faster), closeness of languages (Arabic speakers learned more quickly than speakers of other languages), formal education and managerial, clerical or professional employment (as opposed to manual or unskilled work). Jews from Arabic speaking countries accepted many of the values established by the Ashkenazic-dominant society, including the shift to Hebrew. North African Jews, many of them bilingual in at least Maghreb Arabic and French (often their language of education), soon moved to add Hebrew to their linguistic repertoire. In some families, Arabic was dropped and French retained as a home language alongside Hebrew; in others it was vernacular Arabic that 
continued as the language of the first generation, with passive knowledge passed on to later generations (Ben-Rafael, 1994: 84).

Hebrew has thus continued to penetrate immigrant groups, succeeding often in a generation or two to replace the original language. And yet there are exceptions. Some older members of the first generation were slow to learn Hebrew, thus contributing to the maintenance of their language in the home and community. Second, where there was a concentration of population sharing a language other than Hebrew, the linguistic homogeneity contributed to its preservation. This could be seen in some earlier groups of German- and English-speaking immigrants, and in groups of immigrants settled in a single neighbourhood or in a single cooperative agricultural settlement (moshav). This tendency is nowadays most noticeable among the recent immigrants from Ethiopia and the former Soviet Union.

As Fishman (1966) pointed out more than 30 years ago, groups that are not permitted or that do not choose social integration and upward social mobility are most likely to resist language shift. This fact is most obviously demonstrated by the ultra-orthodox Jews, a part of whom maintain Yiddish as the language of instruction in their segregated schools and the language of speech in their closed communities. In the last decade, the knowledge of Modern Hebrew has grown even among the ultra-orthodox, so that there are Hasidic sects who use this language at home. Ultra-orthodox education, however, continues to use Yiddish as a language of instruction.

The dominant culture in Israel emphasised the imperative of building an integrated and culturally homogeneous nation; Hebrew, the renewed national language, was to be the matrix for the new setting. Among veteran European groups, this linguistic transformation was pursued by persistent attrition of the languages of origin, a process that began even before Hebrew had been fully mastered. Much like the Ashkenazim, the north African and Middle Eastern communities turned to Hebrew without reservation, although this switch often implied less total and immediate abandonment of diaspora languages (Ben-Rafael, 1994: 221).

It might seem obvious that an institution that calls itself Hebrew University will perceive the promotion of the Hebrew language as one of its main objectives. Due to the fact that during the period of 30 years (until 1955) this was the only recognised institute of higher education in Eretz-Israel in the field of humanities (teaching and research in natural and engineering sciences also took place in Technion and Ziv (later called after Chaim Weizman) Institute of Science), and taking into account the role of the Zionist movement in its creation, one can assume that the University in Jerusalem played an outstanding part in the revitalisation of Hebrew, its development and spread. However, historical analysis of the relevant sources does not always support this hypothesis.

However, as stated by Anita Shapira (1996: 185):

The University played a somewhat marginal role in the young Zionist movement ... In European national movements - in Czech nationalism for example - the university played a central role in the revival or creation of a national culture: The language, the national epic, the 
folklore were all cultivated and nurtured by the university. This was not the case in the Jewish renaissance: The cultural revolution took place outside of academia. The most cardinal phenomenon in this context - the revival of the Hebrew language - had no connection whatsoever to academic bodies. Eliezer Ben-Yehuda's ${ }^{2}$ philological innovations, along with the practical work carried out by teachers in the First Aliya colonies, and the Second Aliya laborers' insistence on speaking Hebrew, brought about the dissemination of Hebrew as a spoken language. Scholars of modern Hebrew appeared after the language itself had come into existence, and they made only a marginal contribution to its dissemination.

Anita Shapira argues that the university's marginal role in the cultivation of a national culture during the formative years of the Zionist movement stemmed from the fact that the Hebrew University was not a catalyst of the national movement, but was instead a result of the movement's emergence.

By the time the Hebrew University was established in the mid 1920s, a secular Hebrew cultural infra-structure was already in existence, independent of the academy. This was a fact of major importance in determining the university's place in the local society. (Shapira, 1996: 186)

Although the first Jewish secular institution of higher education was named the Hebrew University of Jerusalem, the majority of its students and teachers did not speak Hebrew as their mother tongue. Spolsky and Shohamy (2001: 169) argue that this name 'proclaimed clearly a commitment to the Hebrew language, which was quickly entrenched in the University's constitution and regulations'. However, it seems that the situation was more complicated. Indeed, in his address presented at the opening ceremony of the Institute of Jewish Studies (the first department founded at the Hebrew University) in December 1924, Judah Leib Magnes, later to become the first chancellor and the first president of the Hebrew University, announced: '... The language of instruction is Hebrew - (There was no dispute on that except from a few Yiddishists)' (cited in Bentwich, 1954: 156). However, the proclaimed policy turned to be rather hard to follow: Magnes himself usually prepared his speeches first in English, and only after that - in Hebrew (Bentwich, 1954: 231). Professor Selig Brodetsky, who was elected President of the University in May 1949, decided 'to decline to lecture on aerodynamics at the Hebrew University' because his 'lack of acquaintance with technical terms in Hebrew' (Brodetsky, 1960 [1954]: 295). This example illustrates the problems concerning the spread of the Hebrew language in the Hebrew University 25 years after its foundation. It is obvious that these problems were much more serious in the pre-state period, during the first years of the university.

According to the information collected in the Hebrew University archive, in 1948, when the State of Israel was established, there were no Hebrew University graduates among Hebrew University professors (see Table 1). There was only one Jerusalem alumnus among the lecturers (Menahem Max Schiffer, appointed in 1947). In addition, there were six Jerusalem graduates among the instructors, three among research fellows and six among the 
Table 1 The Hebrew University academic staff, 1948, according to the last place of higher education

\begin{tabular}{|l|c|c|c||}
\hline & $\begin{array}{c}\text { Professors } \\
\text { and } \\
\text { associate } \\
\text { professors }\end{array}$ & $\begin{array}{c}\text { Lecturers, instructors, } \\
\text { research fellows and } \\
\text { academic assistants }\end{array}$ & Total \\
\hline $\begin{array}{l}\text { Germany and other mostly } \\
\text { German-speaking countries } \\
\text { (Switzerland, Austria and } \\
\text { Czechoslovakia) }\end{array}$ & $32(68 \%)$ & $56(64 \%)$ & $88(65 \%)$ \\
\hline $\begin{array}{l}\text { English-speaking countries } \\
\text { (Britain, USA and Australia) }\end{array}$ & $5(11 \%)$ & $6(7 \%)$ & $11(8 \%)$ \\
\hline Italy & $6(13 \%)$ & $4(5 \%)$ & $10(7 \%)$ \\
\hline France & - & $4(5 \%)$ & $4(3 \%)$ \\
\hline Russia and Poland & $4(9 \%)$ & $2(2 \%)$ & $6(4 \%)$ \\
\hline Hebrew University & - & $16(18 \%)$ & $16(12 \%)$ \\
\hline Total & 47 & 88 & 135 \\
\hline
\end{tabular}

Source: Original table based on information collected in the Hebrew University archive.

Hebrew University assistants ${ }^{3}$ (see Table 1). However, only one of the faculty members (Leah Frankenthal-Bloch) was born in Palestine/Eretz-Israel; all the other Hebrew University graduates were born in Russia, Germany and other diaspora countries (see Table 2). Hebrew was neither their native nor first language.

Israel had benefited immensely from the influx of gifted refugee scientists and scholars from Germany and other European countries defeated and occupied by Nazis. The research data demonstrates that during the first year of the Israeli statehood the majority of the Hebrew University academic staff (68\% among the professors, $64 \%$ among the lecturers and assistants) studied at the universities, where the language of teaching, instruction and research was German. It should not be forgotten that in the 19th century the higher educational system of Germany was considered the finest in the world. Many foreign students came there to complete their studies. The university professor in Germany enjoyed the highest prestige, because of the high value placed on education in German culture and because the universities were located mainly in small towns whose entire life and economic sustenance depended upon them. The university professors were 'an extremely hard working and productive group, whose highest duty was the advancement of science in a tradition of careful scholarship' (Oberschall, 1965: 10). The dominance of the 'German professors' within the Hebrew university lasted for several decades. It was not before 1965 that a Jerusalem graduate (Nathan Rotenstreich) became for the first time the Rector of the Hebrew University. 


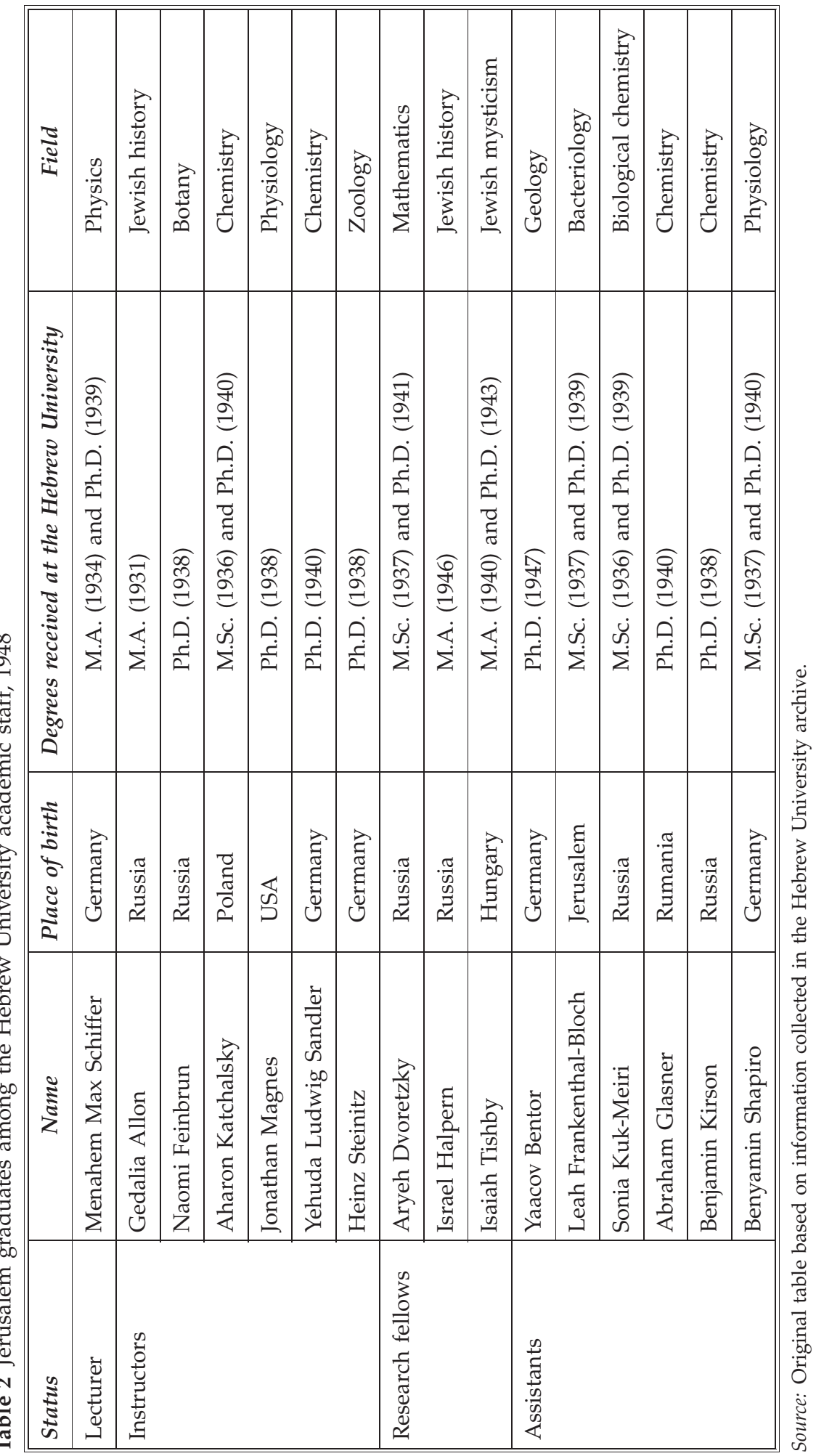


The second Israeli university - the Haifa Technion, Israel Institute of Technology - was established in 1924 as well. It was to be a pragmatic institution devoted to technological and technical needs, first and foremost to the instruction of train engineers and architects. As mentioned by Ben-David (1986: 107), the model for both the Hebrew University and the Technion were 'the universities and technological high schools in Germany, which were considered at that time as the best in the world, and were the best known to the teachers recruited to the new institutions'. Ben-David even argued that 'the Hebrew University in about 1940 probably adhered to the Humboldtian idea of unity of research and teaching more than had any university anywhere in the world (including Germany) before' (Ben-David, 1986: 109). This phenomenon can be explained by the fact that in Israel training specialists was not an important function of the university, because immigration brought to the country more than enough professionals, and any addition to their number could only have made worse an already poor employment situation (this state of affairs, caused mostly by the rise of Hitler's regime which resulted in the immigration of highly qualified specialists of the German Jewish origin, was, of course, hard to predict when the Technion was founded). Therefore, the only students who took the University seriously were those who had genuine personal interest in science and learning, even at the cost of economic sacrifice. As a result, Technion was conceived not only in principle, but also in fact, as primarily a research institution (see Katz, 1997: 429-454). In the words of Ben-David (1986: 109), 'the Haifa Technion did not develop an alternative tradition competing with the Humboldtian - Ahad Ha'Amian tradition of the Hebrew University ... [and] became a high level technological university'.

The influence of the German model was so strong, that when the first plans were made for the establishment of the Haifa Technion in 1913, it was envisaged that the language of instruction would be German. A German-Jewish philanthropic organisation, Hilfsverein der Deutschen Juden, took much of the responsibility for the initial organisation of the institution and demanded German be the language of instruction for the sciences. Like parallel French or English educational societies they intended that Jewish topics be taught in Hebrew but secular ones would be offered in the language of the sponsoring organisation. In this manner they expected Jewish youth in Palestine to acquire a valuable tool that would provide access to a major European society (Troen, 1992: 53). This proposal was strongly resisted by teachers and pupils in the schools, and yielded a number of public demonstrations and petitions. The pro-Hebrew campaign was successful, and in February 1914, the Technion's Governing Board reversed its position, agreeing that Hebrew would be used for mathematics and physics when the school opened, and that other subjects should follow. Thus, when the Technion finally opened in 1924 Hebrew was the only language of instruction in this institution (see Spolsky \& Shohami, 2001: 169). However, most research projects were still conducted in German or in English, the main official language of the mandate authorities. 


\section{From German-Hebrew Bilingualism to the Dominance of English as a Language of Science}

In his classical book The Language of Science, published half a century ago, Theodore Savory (1953: 152) emphasised that

It is instructive to recall the advice that at one time was commonly given to young scientists, given with every desire to be helpful. It was that they should learn to read German. Indeed at one time it was almost true to say that the language of science was the language of Heidelberg and Gottingen. The advice was undoubtedly justified. ... Many scientists will agree that in the first forty years of the [twentieth] century it was if not impossible at least exceedingly difficult to keep abreast of any branch of biology or medical science if one did not read German. I suspect that probably the same was true of other branches of science with which I cannot claim the same acquaintance. Yet, as we daily realize, times change; the results of biological and medical research in Germany have been very meagre during the period since 1939, and there does not seem to be much evidence that they will become appreciably greater for some time.

T. Savory draws the readers' attention to the fact that during the first four decades of the 20th century scientists in the far east, in Denmark and the Scandinavian countries, used to publish the results of their research in German. 'They knew that, for example, the Japanese and Norwegian languages were not widely read outside their own countries, and they sought greater appreciation of their efforts by having their work translated into a language more widely understood' (Savory, 1953: 153). However, after World War II the scientific works in these and other countries have been very extensively published in English: with the ever-expanding and very practical interest in science, both in America and in many parts of the former British Empire, English showed signs of becoming the language of science.

Those days the situation in Israel was quite similar to the general dynamics discussed by T. Savory, although the formative years of Israeli state-building are usually perceived as a period of 'melting pot' and 'Hebrew only' politics. David Ben-Gurion, Israel's most influential political leader and its prime minister in 1948-1953 and 1955-1963, was deeply committed to these politics. However, the linguistic orientation of the universities was quite different. Hebrew did not receive recognition as a most respected language within the campus. During the first 15 years of Israel's political independence its institutions of higher education changed their orientation from the German Humboldtian model to the American one. Simultaneously, English replaced German as a major language of science. As mentioned by Ben-David (1962: 12)

Israel, alongside the Scandinavian countries, has become sharply aware of the shift of the main currents of scientific endeavor from Europe to America since the Second World War. As a result an increasing number of Israeli students and scientists have gone to study in the U.S., and Israeli institutions of higher education and research, originally 
patterned on European models, have been transformed during the last twelve years, chiefly under American influence. Finally, the facilities available for research, have been constantly improved and modernized. In this process American technical and financial aid has also played a major role.

During Israel's first decade of independence the Hebrew University was a dominant factor in the construction of 'credential society culture' (Cohen, 2001). Definition of this culture relies upon the creation of specific codes relating to the structure of a set of priorities that the society constructs, in the creation of new kinds of elite groups and in demands for cultural supremacy. This model established rates and gates that were constructed to regulate and supervise the process of output and flow of resources in the new sovereign society. As emphasised by Cohen (2001), this process was dominated by a powerful new principle relating to stratification, which gave way to the establishment of exclusive bordering and prevented the 'strangers' who had just arrived in Israel from gaining access to the social group.

During the first 15 years of Israeli statehood the staff policy of its institutes of higher education changed drastically. According to the data collected in the Hebrew University archive, $65 \%$ of all its faculty members who taught at the University in the year of proclamation of Israel's political independence (1948), studied in Germany, Austria and German-speaking regions of Switzerland. However, the alumni of the German-speaking universities constituted only $2 \%$ among 87 new faculty members, who finished their PhD studies and were recruited by the Hebrew University's departments of humanities and social sciences during the next 15 years (see Table 3). The vast majority of the new faculty members were Hebrew University graduates (56\%), whereas $30 \%$ of the newly appointed lecturers finished their studies in the USA, Britain and other English-speaking countries. Some of them were born and began their studies in Palestine/Eretz-Israel, but chose to conduct their PhD research in various American and/or British universities. In several fields, mostly those related to social sciences, American and British alumni constituted the majority of new teachers (see Table 3 and Figure 1) and the largest group of faculty members $(42 \%)$ within their departments (see Table 5). During the formative years of the Israeli statehood, which are usually perceived as an epoch of state-mediated messianic nationalism (this perception being mostly justified), the institutes of higher education became the arena of the 'silent revolution', the direction of which contradicted the nationalist mainstream. The ideology of globalisation and Americanisation, opposite to that of independent nation-building, clearly manifested its prevalence within the campus.

Tables 3-5 help get an impression of the enormous intensity with which the shift in the Hebrew University's staff policy took place. It should be pointed out, however, that the trends that made up this change differed both with respect to the faculty (the Social Sciences versus the Humanities), as well as, when the faculty of Humanities was concerned, the field of studies (Jewish studies versus the General Humanities). 
Table 3 New faculty members who finished their PhD studies between 1949 and 1962, according to the last place of higher education $(\mathrm{PhD})$

\begin{tabular}{|l|c|c|c|c|c||}
\hline & $\begin{array}{l}\text { Jewish } \\
\text { studies }\end{array}$ & $\begin{array}{c}\text { General } \\
\text { humanities }\end{array}$ & $\begin{array}{c}\text { Social } \\
\text { sciences }\end{array}$ & \multicolumn{2}{|c|}{ Total } \\
\hline $\begin{array}{l}\text { German-speaking } \\
\text { countries }\end{array}$ & 1 & - & 1 & 2 & $2 \%$ \\
\hline English-speaking countries & 2 & 9 & 15 & 26 & $30 \%$ \\
\hline Other foreign countries & 1 & 6 & 3 & 10 & $11 \%$ \\
\hline Hebrew University, Jerusalem & 16 & 22 & 11 & 49 & $56 \%$ \\
\hline Total & & & & 87 & $100 \%$ \\
\hline
\end{tabular}

Source: Original table based on information collected in the Hebrew University archive.

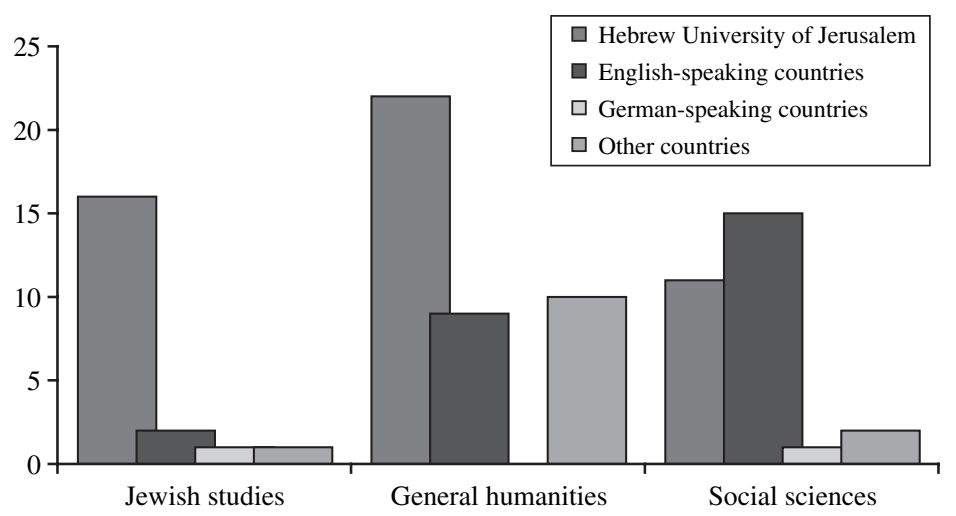

Figure 1 New faculty members who finished their PhD studies between 1949 and 1962, according to the last place of higher education (PhD).

So, as can be seen from Table 4, in 1948, $67.5 \%$ of the Faculty of Humanities academic staff graduated from universities in German-speaking countries, whereas the proportion of the Hebrew University alumni was minor (3 out of 40 faculty members). In 1963, however, a cardinal change took place. The proportion of Hebrew University graduates among the faculty members grew rapidly (51 out of 109), whereas not only the percentage, but also the absolute number of the former students of the universities in German-speaking countries decreased notably, being $23(21.1 \%)$, as opposed to $27(67.5 \%)$ in 1948.

It should be mentioned that the increase in the proportion of the Hebrew University alumni among the Faculty of Humanities academic staff was uneven with respect to the field of specialisation. So, in 1963, among those engaged in Jewish studies, the majority had graduated from the university they worked in (55\% as opposed to $17 \%$ in 1948). As Table 3 demonstrates, the tendency those days was to prefer Hebrew University graduates when recruiting new academic staff: among 20 new faculty members engaged in Jewish studies 16 were 'home made'. 
Table 4 The Faculty of Humanities academic staff, 1948 and 1963, according to the last place of higher education (MA or $\mathrm{PhD}$ )

\begin{tabular}{||l|c|c|c|c||}
\hline \multirow{2}{*}{} & \multicolumn{2}{|c|}{1948} & \multicolumn{2}{c|}{1963} \\
\cline { 2 - 5 } & $\begin{array}{c}\text { Jewish } \\
\text { studies }\end{array}$ & $\begin{array}{c}\text { General } \\
\text { humanities }\end{array}$ & $\begin{array}{c}\text { Jewish } \\
\text { studies }\end{array}$ & $\begin{array}{c}\text { General } \\
\text { humanities }\end{array}$ \\
\hline $\begin{array}{l}\text { Germany and other German- } \\
\text { speaking countries }\end{array}$ & $11(61 \%)$ & $16(73 \%)$ & $11(26 \%)$ & $12(18 \%)$ \\
\hline $\begin{array}{l}\text { English-speaking countries (Britain, } \\
\text { USA, Canada and South Africa) }\end{array}$ & $1(6 \%)$ & $5(23 \%)$ & $5(12 \%)$ & $16(24 \%)$ \\
\hline Other foreign countries & $3(17 \%)$ & $1(5 \%)$ & $3(7 \%)$ & $11(16 \%)$ \\
\hline Hebrew University of Jerusalem & $3(17 \%)$ & $0(0 \%)$ & $23(55 \%)$ & $28(42 \%)$ \\
\hline Total & $18(100 \%)$ & $22(100 \%)$ & $42(100 \%)$ & $67(100 \%)$ \\
\hline
\end{tabular}

Source: Original table based on information collected in the Hebrew University archive.

Table 5 Social science faculty members, 1948 and 1963, according to the last place of higher education $(\mathrm{PhD})$

\begin{tabular}{|l|l|l|}
\hline & \multicolumn{1}{|c|}{1948} & 1963 \\
\hline Germany and other German-speaking countries & $6(60 \%)$ & $6(14 \%)$ \\
\hline Germany & 2 & 2 \\
\hline Austria & 3 & 2 \\
\hline German-speaking region of Switzerland (Zurich) & 1 & 2 \\
\hline English-speaking countries & $1(10 \%)$ & $18(42 \%)$ \\
\hline USA & 0 & 14 \\
\hline Britain & 1 & 3 \\
\hline South Africa & 0 & 1 \\
\hline Italy & $3(30 \%)$ & $1(2 \%)$ \\
\hline France and other French-speaking countries & $0(0 \%)$ & $5(12 \%)$ \\
\hline France & 0 & 3 \\
\hline French-speaking region of Switzerland (Geneva) & 0 & 2 \\
\hline Spanish-speaking countries of South America & $0(0 \%)$ & $1(2 \%)$ \\
\hline Hebrew University of Jerusalem & $0(0 \%)$ & $12(28 \%)$ \\
\hline Total & 10 & 43 \\
\hline
\end{tabular}

Source: Original table based on information collected in the Hebrew University archive. 
In the field of General Humanities, however, the picture was more polychrome. Indeed, whereas in 1948 there were no Jerusalem graduates among the staff members engaged in General Humanities, in 1963 their proportion constituted $42 \%$ (28). As follows from Table 3, in the field of General Humanities, 22 out of 37 new recruits who had finished their studies between 1949 and 1962 were Hebrew University alumni. Yet, a significant growth in the number of graduates from universities in non-German-speaking countries took place as well (27 in 1963 as opposed to 6 in 1948).

To summarise, it is important to emphasise that the status of the Hebrew University as a supplier of the academic staff in the field of Humanities strengthened in the early 1960s. A new generation of scholars was fostered that could compete with the graduates of the leading American and European universities. Moreover, in the field of Jewish studies, Jerusalem graduates seemed to be considered the experts and were preferred to the other candidates available. Yet, when the General Humanities were concerned, the competition between the Hebrew University graduates and the alumni from other countries was far less predetermined, so that the proportion of the former students of the universities in non-German-speaking countries among the academic staff grew rapidly as well.

A different trend, however, manifested itself in the faculty of the Social Sciences. As in the Humanities, the staff situation in this faculty was characterised by the decline in the proportion of graduates from universities in German-speaking countries. So, in 1948, 60\% of the Social Sciences faculty members had finished their studies in German-speaking countries. Yet among 30 new recruits who finished their studies between 1949 and 1962, there was only one teacher who did so in a German-speaking environment.

By the same token, the relative weight of the Hebrew University alumni increased radically: whereas in 1948 there were no Jerusalem graduates among the Social Sciences faculty academic staff, in 1963 their proportion constituted almost a third (12). However, although the growth in the number of Jerusalem graduates was rapid, the increase in the proportion of graduates from the universities in English- and French-speaking countries was even faster: so in 1948 only one staff member (Norman Bentwich, who studied in Britain) belonged to this category, whereas 23 (54\%) did so in 1963. Among those 23 staff members, the majority (18) had finished their studies in an Englishspeaking country; 14 (out of 18) had done so in the USA.

Thus, it follows that the staff policy dynamics in the Hebrew University varied with respect to the faculty. Indeed, in the year the State of Israel was founded, both the Social Sciences and the Humanities were characterised by the dominance of graduates from German-speaking countries. In both cases this dominance gave way to being a minority by the early 1960s. Yet, as opposed to the Humanities, at the faculty of the Social Sciences it was not the Hebrew university graduates, but the alumni of the universities in the Englishspeaking countries who constituted a prevailing group by the end of the period described.

It should be mentioned that in 1963 the Hebrew University was not the only institution of higher education in Israel. The university-level institutions established after 1955 (among them Bar-Ilan University, founded in 1955, 


\begin{tabular}{|c|c|c|c|c|c|c|c|c|c|c|}
\hline 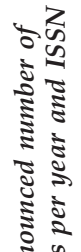 & 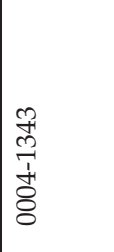 & $\begin{array}{l}x \\
\infty \\
o \\
+1 \\
1 \\
o \\
\& \\
8\end{array}$ & 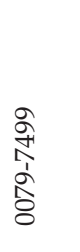 & 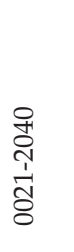 & 1 & 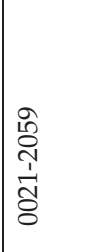 & 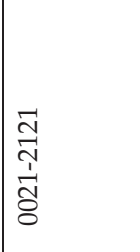 & 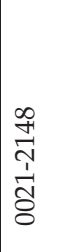 & 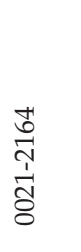 & $\begin{array}{l}\text { N } \\
\stackrel{N}{\Lambda} \\
\stackrel{-}{\Delta} \\
\delta\end{array}$ \\
\hline $\begin{array}{l}\overline{5} \\
.\end{array}$ & $H$ & $N$ & $\tau$ & $\cong$ & - & $\sim$ & - & $r$ & $H$ & 0 \\
\hline 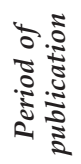 & ঐু & 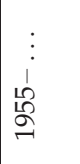 & \begin{tabular}{l}
0 \\
\multirow{2}{2}{} \\
1 \\
$\vdots$ \\
8 \\
2 \\
2
\end{tabular} & $\begin{array}{l}\bar{\sigma} \\
\sigma \\
1 \\
1 \\
\qquad \\
\sigma\end{array}$ & 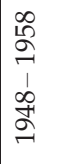 & 命 & 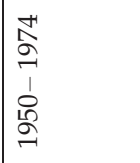 & ळू & \&ু & ᄋ్ర \\
\hline$\widetilde{\Xi}$ & 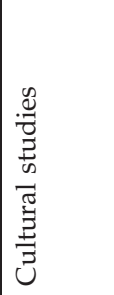 & 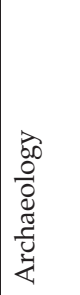 & 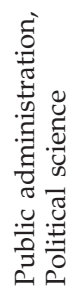 & 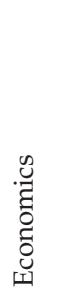 & 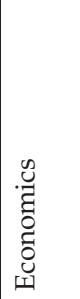 & 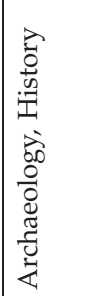 & 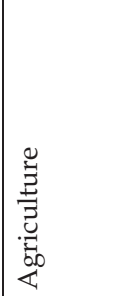 & 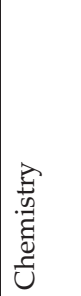 & $\begin{array}{l}\overrightarrow{0} \\
\stackrel{0}{8} \\
\stackrel{8}{0}\end{array}$ & 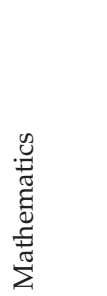 \\
\hline 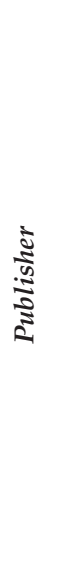 & 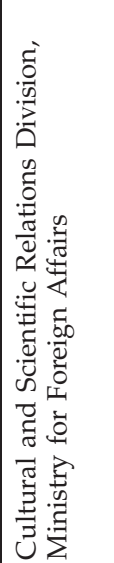 & 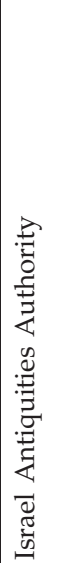 & 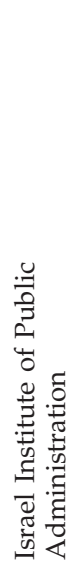 & 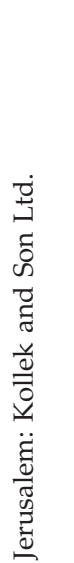 & 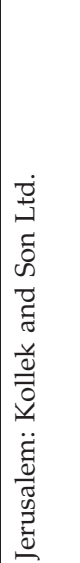 & 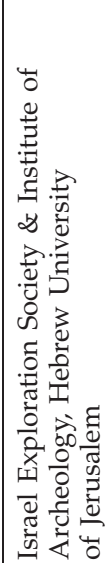 & 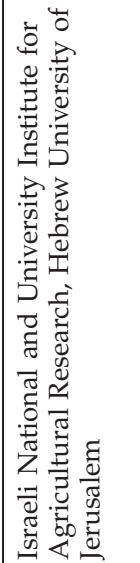 & 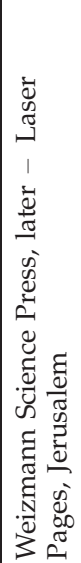 & 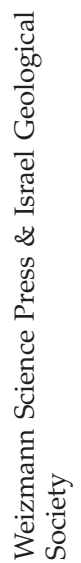 & 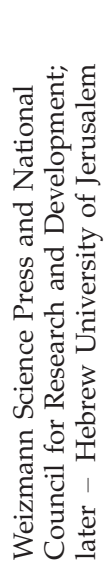 \\
\hline 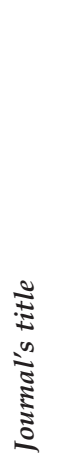 & 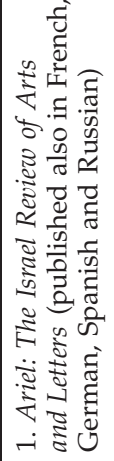 & 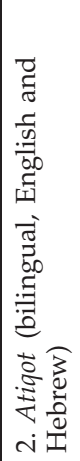 & 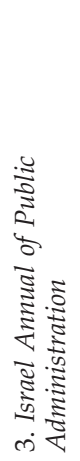 & 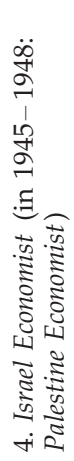 & 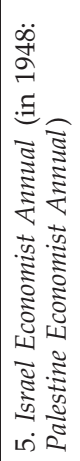 & 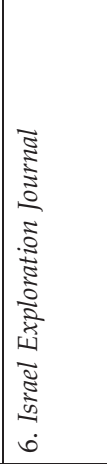 & 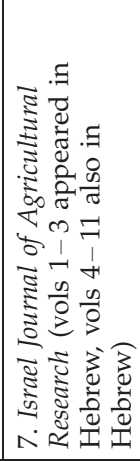 & 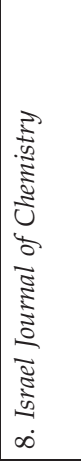 & 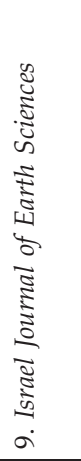 & 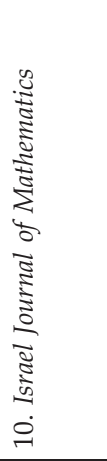 \\
\hline
\end{tabular}




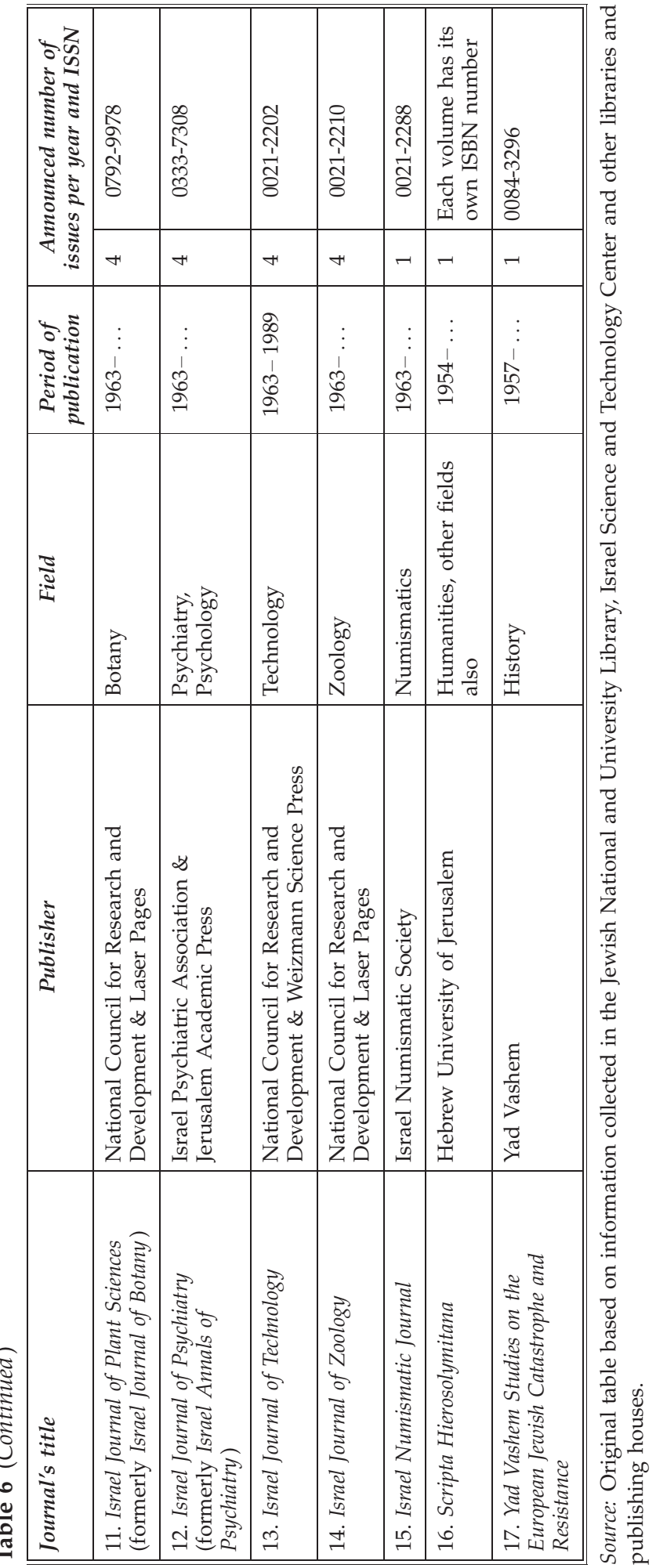


Tel-Aviv University, founded - as a branch of the Hebrew University - in 1957, 4 and the University of Haifa and Ben-Gurion University, which were founded during the 1960s) tended to follow the Humboldtian model adopted by the two veteran institutions - the Hebrew University and the Technion (Guri-Rosenblit, 1999: 93). Nonetheless, the processes of Americanisation and Anglicisation, which took place in Jerusalem, evidently influenced all the Israeli universities.

The high status of the Hebrew University and its almost monopolistic position in the country can be mentioned among the most influential reasons responsible for this metamorphosis. After 15 years of political independence, Israel, then a country with a population of less than 2.5 million, had only one university that possessed fully fledged faculties of natural science, humanities, social sciences, law, medicine, agriculture and schools of social work, dentistry and librarianship. Its social science and law faculties also had branches in Tel-Aviv. There were two additional relatively small universities, the Bar-Ilan University in Ramat-Gan, and the Tel-Aviv University, engaged in teaching and (only to a very limited extent) in research. The total of students in all the institutions of higher education was relatively small (approximately 13,000), while the majority of them studied at the Hebrew University. Thus, it was this university that set the standards for all the other institutions, at least in the fields of humanities and social sciences.

It should be mentioned that, in addition to the fact that the majority of Israeli scholars publish their research findings outside Israel, most Israeli scientific and semi-scientific journals in exact and natural sciences, as well as in humanities are published in English as well. According to the data collected in the current research, 17 scientific and semi-scientific journals in English were founded in Israel during the Ben-Gurion era (1948-1963); among them nine in the field of Judaism, Jewish history, archaeology, arts and Israeli economics and public administration (see Table 6).

\section{Modernity/Globalisation versus Nation Building within Academia: Concluding Remarks}

The discussion concerning the processes of Americanisation and Anglicisation in Israeli universities in the late 1950s to the early 1960s can be illustrated by a citation from Joseph Ben-David's essay, published in 1962:

... Until about 1949 ... the country had been isolated from scientific centers. ... The way and the extent to which contact with 'metropolitan' (which is at present mainly American) science corrected some of the shortcomings inherent in small size can be seen from the developments in Israel since 1949. There has been a constant flow of students and scientists to and from America, and to a lesser extent other countries, and local achievements are constantly held up to the mirror of universal standards.... Some institutional changes have taken place. It is an unwritten but consistently enforced rule that one has to publish in English, and, for senior appointments, in 'central' publications. (Ben-David, 1962: 14) 
One can assume that, regarding the issues discussed by Ben-David, the situation has not changed until now. Recently conducted research demonstrated that English is a crucial factor, which shapes the patterns of the immigrant scientists' integration into the Israeli scientific institutions (Kheimets \& Epstein, 2001). The Israeli universities have become one of the most faithful adherents of the 'English only' policy.

Regarding the first hypothesis, suggested in the beginning of the paper, our conclusion is that, although most scholars shared a moderate liberal version of Jewish nationalism (see Epstein, 2001; Shapira, 1996), this orientation did not influence the choice of Hebrew as a primary language of communication and publication (to use Hebrew for scientific writing in Israel when this language is unknown elsewhere may signify condemning the University to isolation). On the other hand, teaching has always been held in Hebrew - in the overwhelming number of courses - and it is in this language that examinations, seminar works, most MA theses and dissertations have been written. In the pre-state and the early state period, the native speakers of German and graduates of universities in which German was the language of teaching and research, were de-facto acknowledged as the most privileged and promoted group of scientists. Later they were replaced by the English-speaking graduates of various American and British universities.

Regarding the second hypothesis it seems obvious that the Eretz-Israel's first universities were not characterised by a pattern of multilingualism. At their formative stage German was the language of publishing, research and communication within the scholars' community, whereas Hebrew became the language of teaching and instruction. Later the role and the status of Hebrew have not really been expanded, whereas English replaced German in all of its functions.

In accordance with the third hypothesis, as elsewhere in the world, English became the dominant language within the Israeli scientific and semi-scientific community. No other languages played a significant role in the Hebrew University of Jerusalem and the Haifa Technion. Academics' mission as bridge-makers and translators was relatively limited.

The phenomenon discussed in this essay should not be underestimated by historians and sociologists, especially provided the fact that Israel is traditionally perceived as one of the most successful and impressive instances of nation building in the 20th century. The interpretation suggested above challenges the general sociological assumptions about the role of intellectuals in Israeli nation building and contradicts the conventional explanation regarding the Israeli state-building process. Intellectual life within the Jewish community in the mandatory Palestine did not emerge as a direct and exclusive result of a specific political will - Zionism - but rather as an outcome of a wider project: that of modernity (Trajtenberg, 2002). For well over a century, Jewish intellectuals - and especially those German-Jewish scholars who constituted the mainstream of the Jewish philosophy in the last century had been having serious doubts concerning the legitimacy and desirability of harnessing the interests of the Jewish people to the worldly power of a political state. Although many prominent scholars not only participated in the Zionist movement actively, but also became personally dependent on the 
political success of the Zionist project after their immigration to Palestine, their loyalty to the political leaders of the Yishuv and the state was limited by their sense of truth and justice (see Epstein, 2001). Scholars' linguistic choices were determined not only by their desire for integration into 'international science', which was mediated mostly in German (in the beginning of the 20th century), and later in English, but also by their disengagement from the spiritual world and goals of Jewish nationalism, which attributed the greatest importance to the revitalisation of Hebrew. Academics' self-isolation and only partial participation in the Hebrew cultural revival were also an expression of their discomfort both with the materialisation of Jewish nationalism and with some features of Israeli state building.

Juxtaposing the trends evident in academia with those that characterise broad Israeli society, the following consequences seem to be likely.

First, Hebrew being a major factor which bounds and unites various groups of Israeli Jewish society, academia's 'language shift to English' is likely to threaten one of the essential achievements of Israeli nation-building.

Second, as pointed out by Kuzar (2001: 34), 'in order to be fully relevant to mainstream national culture, not just in the academic sphere, one will have to resort to one's national language'. Therefore, the 'abandoning' of Hebrew might lead to the relative isolation of higher education and research from the rest of society, thus minimising the societal benefits from academic activities.

Third, today's high status of English as an uncontroversial linguistic capital in the Israeli academic community would preserve and broaden the gaps between various strata within general society.

Fourth, as pointed out by Harshav (1993: 175), 'without the continuous development of a rich language of texts, there is not a full life either for the individual or for the society'. The current situation is likely to hamper the development of the original Israeli culture, the main medium of which has been Hebrew.

Finally, the universities, which played a central role in the revival or creation of national cultures in various national movements, nowadays seem to function as agents of globalisation at the expense of the original native culture.

\section{Acknowledgements}

This paper originated from research conducted by the first author at the Bar-Ilan University in the framework of her doctoral studies supervised by Professor Bernard Spolsky. We would like to thank two anonymous reviewers for their most helpful comments and constructive criticisms.

\section{Correspondence}

Any correspondence should be directed to Nina G. Kheimets, Department of English, Bar-Ilan University, P.O. Box 27123, Jerusalem 91271, Israel (nina_kheimets@yahoo.com).

\section{Notes}

1. The abridged version of the paper was presented at the session 'Historical Sociology' at the 6th Conference of the European Sociological Association (Murcia, Spain, September 23-26, 2003). 
2. However, it should be mentioned that Eliezer Ben Yehuda was a member of the third Hebrew University organising committee which was formed in Jerusalem in 1922 (see The Hebrew University. Jerusalem. Its History and Development, 1948: 4). His sudden death the same year did not permit him to participate actively in the creation of the Hebrew University of Jerusalem.

3. Our enquiry demonstrates that Bentwich's (1961: 159-160) statement that in 1948 only two research fellows and four instructors were alumni of the Hebrew University is incorrect.

4. Several years later this institution was recognised as an independent university.

\section{References}

Bachi, R. (1956) A statistical analysis of the revival of Hebrew in Israel. Scripta Hierosolymitana 2, 179-247.

Ben-David, J. (1962) Scientific endeavor in Israel and the United States. American Behavioral Scientist 5, 12-16.

Ben-David, J. (1986) Universities in Israel: Dilemmas of growth, diversification and administration. Studies in Higher Education 11 (2), 105-130.

Bendix, R. (1969) Nation-Building and Citizenship. Studies of Our Changing Social Order. Garden City, NY: Doubleday-Anchor Books.

Ben-Rafael, E. (1994) Language, Identity, and Social Division: The Case of Israel. Oxford: Oxford University Press.

Bentwich, N. (1954) For Zion's Sake. A Biography of Judah L. Magnes. Philadelphia: The Jewish Publication Society of America.

Bentwich, N. (1961) The Hebrew University of Jerusalem, 1918 -1960. London: Weidenfeld and Nicolson.

Brodetsky, S. (1960 [written in 1954]) Memoirs. From Ghetto to Israel. London: Weidenfeld and Nicolson.

Butterfield, H. (1966) The Origins of Modern Science. New York: Free Press.

Cohen, U. (2001) The Hebrew University of Jerusalem in the transition from Yishuv to State: Initial perspectives on the development of the credential society in Israel. Zionism - Studies in the History of the Zionist Movement and of the Jewish Community in Palestine 23, 297-329 [in Hebrew].

Cooper, R. (1984) A framework for the description of language spread: The case of modern Hebrew. International Social Science Journal 36 (1), 87-112.

Edwards, J. (1985) Language, Society and Identity. Oxford: Basil Blackwell.

Epstein, A. (2001) Defending democracy and civil rights: Jerusalem's academic community in the era of state-building. Jewish Political Science Review 13 (1-2), 63-103.

Ezrahi, Y. (1974) The authority of science in politics. In A. Thackray and E. Mendelsohn (eds) Science and Values (pp. 215-251). New York: Humanities Press.

Fishman, J. (1966) Language Loyalty in the United States: The Maintenance and Perpetuation of Non-English Mother Tongues by American Ethnic and Religious Groups. The Hague: Mouton.

Grillo, R.D. (1989) Dominant Languages: Language and Hierarchy in Britain and in France. Cambridge: Cambridge University Press.

Gouldner, A. (1979) The Future of Intellectuals and the Rise of the New Class. New York: Continuum.

Guri-Rosenblit, S. (1999) Changing boundaries in Israeli higher education. Mediterranean Journal of Educational Studies 4 (2), 91-114.

Halpern, B. and Reinharz, J. (2000) Zionism and the Creation of a New Society. Hanover: Brandeis University Press.

Harshav, B. (1993) Language in Time of Revolution. Berkeley: University of California Press.

Jacoby, R. (1987) The Last Intellectuals. American Culture in the Age of Innocence. New York: Basic Books. 
Kaplan, R. (2001) English - the accidental language of science? In U. Ammon (ed.) The Dominance of English as a Language of Science (pp. 3-26). Berlin: Mouton de Gruyter.

Katz, S. (1997) 'Pure science' in a national university. In S. Katz and M. Heyd (eds) The History of the Hebrew University of Jerusalem. Origins and Beginnings (pp. 397-456). Jerusalem: Magnes Press [in Hebrew].

Kheimets, N. and Epstein, A. (2001) The role of English as a central component of success in the professional and social integration of scientists from the former Soviet Union in Israel. Language in Society 30 (2), 187-215.

Kuzar, R. (2001) Hebrew and Zionism. A Discourse Analytic Cultural Study. Berlin: Mouton de Gruyter.

Le Goff, J. (1993 [1957]) Intellectuals in the Middle Ages (T. Lavender Fagan, trans.) Cambridge, MA: Blackwell.

Mannheim, K. (1956 [written before 1933]) The problem of the intelligentsia. In K. Mannheim (ed.) Essays on the Sociology of Culture (pp. 91-170). London: Routledge and Kegan Paul.

Oberschall, A. (1965) Empirical Social Research in Germany. New York: Basic Books.

Savory, T. (1953) The Language of Science. Its Growth, Character and Usage. London: Andre Deutsch.

Shapira, A. (1996) The Zionist Labor Movement and the Hebrew University. Judaism: A Quarterly Journal of Jewish Life and Thought 45 (2), 183-198.

Shatirishvili, Z. (2003) 'Old' intelligentsia and 'new' intellectuals: The Georgian experience. Neprikosnovenniy Zapas 1 (27) [in Russian]; English translation: Eurozine the net-magazine. On WWW at http://www.eurozine.com/article/2003-06-26shatirishvili-en.html.

Shils, E. (1972 [originally published in 1960]) Intellectuals in the political development of the new states. In E. Shils (ed.) The Intellectual and the Powers and Other Essays (pp. 386-423). Chicago: The University of Chicago Press.

Shils, E. (1990) Intellectuals and responsibility. In I. Maclean, A. Montefiore and P. Winch (eds) The Political Responsibility of Intellectuals (pp. 257-306). Cambridge: Cambridge University Press.

Spolsky, B. and Cooper, R. (1991) The Languages of Jerusalem. Oxford: Clarendon Press-Oxford University Press.

Spolsky, B. and Shohamy, E. (2001) The penetration of English as language of science and technology into the Israeli linguistic repertoire: A preliminary enquiry. In U. Ammon (ed.) The Dominance of English as a Language of Science (pp. 167-176). Berlin: Mouton de Gruyter.

Trajtenberg, G. (2002) Plastic arts and nation-building in Israel. Nations and Nationalism $8(2), 215-234$.

Troen, I. (1992) Higher education in Israel: A historical perspective. Higher Education 23, $45-63$. 